\title{
Drying behaviour of unpeeled cashew kernels in steam assisted cross flow dryer
}

\section{BALASUBRAMANIAN AND T.N. SANDEEP}

Received : 17.05.2013; Revised : 22.07.2014; Accepted : 07.08.2014

See end of the Paper for authors' affiliation

Correspondence to :

D. BALASUBRAMANIAN Directorate of Cashew Research, PUTTUR

(KARNATAKA) INDIA Email : bavika13@email.com
- ABSTRACT : The performance of the steam assisted cross flow dryer employed in Indian cashewnut processing industry for drying unpeeled cashew kernels was assessed in terms of drying rate in relation to peeling efficiency. The rate of removal of moisture from unpeeled cashew kernels significantly varied with the location inside the dryer. Cashew kernels placed in close proximity to heat exchanger showed faster diffusion of moisture than other locations inside the dryer. Moisture content of unpeeled cashew kernels was reduced to less than 3.0 per cent (d.b) in the beginning i.e. first $3 \mathrm{hr}$ of drying and reached below 1.0 per cent (d.b) after $9 \mathrm{hr}$ of drying from the initial moisture content of 7.0 per cent (d.b). Movement of humid air towards outlet provided at the top of the dryer and circulation of hot air from bottom to top are the due reasons for the variation in the moisture from the unpeeled cashew kernels inside the dryer. Significant difference was found in the peeling efficiency of unpeeled cashew kernel dried up to $9 \mathrm{hr}$. Practically, moisture content of unpeeled cashew kernels reduced to 1.0 per cent after $9 \mathrm{hr}$ of drying ensured manual peeling process better and kernels dried for 3 or $6 \mathrm{hr}$ period could not attain the required moisture level to ease manual peeling. Total energy required to operate steam assisted cross flow dryer was found to be 16.49 per cent lesser than existing type of dryers in Indian cashewnut processing sector.

- KEY WORDS : Drying, Moisture content, Unpeeled cashew kernels

匹 HOW TO CITE THIS PAPER : Balasubramanian, D. and Sandeep, T.N. (2014). Drying behaviour of unpeeled cashew kernels in steam assisted cross flow dryer. Internat. J. Agric. Engg., 7(2) : 307-312. 